\title{
Diversity of Birds in the Foothills of Phulchoki Hill, Lalitpur, Nepal
}

Praveen Kumar Jha ${ }^{1}$

Abstract : Bird survey was conducted in Phulchoki hill during two different seasons in January 2018 and April 2018. The objective of the study was to identify seasonal avian diversity, and to determine relative abundance and species richness. Fixed radius point- count method was used to evaluate the bird diversity and their number. Shannon-Weiner Diversity Index was used to calculate the diversity of species during two different seasons. A total of 78 species of birds belonging to 7 orders and 24 families were recorded. Passeriformes was the most dominant order with 58 species and Sylvidae was the most dominant family with 14 species. 59 bird species were recorded in winter and 50 in spring seasons. The analysis of data on residential status revealed that 64 species were residents, 10 species winter visitors and 4 species summer visitors. The relative abundance of species was Very Common $(n=16)$, Common $(n=38)$, Uncommon $(n=9)$ and Rare $(n=15)$. Higher Shannon- Weiner Diversity Index $\left(\mathrm{H}^{\prime}=1.488\right)$ was recorded during the winter season and low during the spring season $\left(\mathrm{H}^{\prime}=1.169\right)$. Evenness index showed that birds were evenly distributed in winter season $(E=0.253)$ than spring season $(E=0.207)$. Maximum birds were seen in Mining area during both winter and spring season and minimum birds in the bus park area of Phulchoki due to habitat destruction and human disturbances.

Key words: Avifauna, diversity of species, winter visitors, summer visitors, relative abundance, species richness

Jha, P.K. (2019): Diversity of Birds in the Foothills of Phulchoki Hill, Lalitpur, Nepal. Forestry: Journal of Institute of Forestry, Nepal. No. 16: page 62 to 71.

\footnotetext{
${ }^{1}$ Department of Zoology, Tri-Chandra M. Campus, Tribhuvan University, Nepal Email: jhapraveenkumar8@gmail.com
} 


\section{Introduction}

There are about 10,000 living species of birds in the World. Birds vary in their diversity, habitats, abundance and distribution throughout the World. Birds constitute one of the most important species in the biodiversity of earth. They are sensitive to changes in the environment, and are one of the key indicators of the health of the ecosystem. They are an important part of the food chain and food web. Birds play an important role in maintaining ecological balance; they also indicate the level of pollution (Bibi and Ali 2013). Their help in pollination of flowers and dispersal of seeds is well known.

Nepal's biodiversity strength is well reflected with high number of bird species. There are 886 species of birds present in Nepal, which are about $9 \%$ of total bird species in the world (BCN and DNPWC 2018). Among them, 44 species are enlisted in the IUCN Red List of Globally Threatened (9 Critically Endangered, 8 Endangered and 27 Vulnerable), 35 Globally Near Threatened and 167 species are Nationally Threatened (BirdLife International 2019). The Nationally Threatened species comprise of $67(40 \%)$, which are considered Critically Endangered, 38 (23\%) Endangered and 62 (37\%) Vulnerable Species (Inskipp et al. 2016). Out of 886 species, 650 species are residents, which breed in Nepal. As many as 130 breeding and wintering species (15\% of the Nepal birds) have been assessed as Nationally Threatened (Inskipp et al. 2016). Major habitats of birds include the mountains, forests, wetlands and grassland (BCN and DNPWC 2011). According to Grimmett et al. (2000) forests and bushes contribute $77 \%$ of Nepal's breeding birds. Many Nepal's resident bird species (approximately 550 species) among 886 species are seasonal altitudinal migrants, and these species breed at higher elevations in mountain region and descend to lower altitude for wintering (Inskipp et al. 2016).

Every year about 150 species of migratory birds come to Nepal to spend winter season from northern countries, such as China, Mongolia, Korea, Siberian region of Russia and Central Asia (Jha and Sharma 2018). Similarly, when summer starts in Nepal, about 62 species of summer migrants from the south enter the country for breeding, and other species of birds that migrate from north return to their summer habitats (Baral and Inskipp 2005). Many of these summer visitors come from Sub-Saharan Africa, a journey of more than 5,000 km to Nepal (Bhushal 2013). Others come from South-east Asia, North-east India and South India. All summer visitors that come to Nepal every year inhabit in various forests in the Terai, the hills and the foothills of mountain areas. Most of them stay until October, and then return to their winter habitats (Jha 2016).

There are mainly three types of birds found in the Phulchoki hill. First is the resident birds, which stay the whole year-round and also breed in the area. The 
second is the winter visitor and third type of birds is summer visitor. The avifauna of Phulchoki has been studied in the past (Inskipp 1989, 1993; Lama 1994; Baral 1995; Giri, Chaudhary 2004). A preliminary checklist of birds of this area has already been reported by earlier authors. Despite these works, some areas of Phulchoki hill remained unexplored. Therefore, the present study was undertaken to enrich and augment further information about relative abundance, seasonal diversity and species richness of bird species in Phulchoki hills.

\section{Materials and Methods}

\section{Study Area}

Phulchoki means "Hill of Flowers" in Nepali. Phulchoki hill $\left(27^{\circ} 37^{\prime} \mathrm{N}, 8^{\circ} 16^{\prime} \mathrm{E}\right)$, the highest peak $(2782 \mathrm{~m})$ on the rim of the Kathmandu valley, lies $16 \mathrm{~km}$ southeast of Kathmandu (Figure 1). It mainly comprises limestone and lowgrade metamorphic marble. The temperature of Phulchoki varies from $2^{\circ} \mathrm{C}$ (winter) to $27^{\circ} \mathrm{C}$ (summer), and receives an average annual rainfall of $1735 \mathrm{~mm}$. Among 27 Important Bird Areas (IBAs) in Nepal, Phulchoki hill is one of them (BirdLife International 2019). The lower slope of the Phulchoki mountain forest is managed by seven Community Forest Users Groups (CFUGs) whereas the upper slope is managed by the District Forest Office (DFO) (BirdLife International 2008). There is a marble quarry on the lower slopes. The Mahadeva temple and two springs (place of pilgrimage) at the mountain's base are revered by Hindus, and a festival is held here every 12 years.

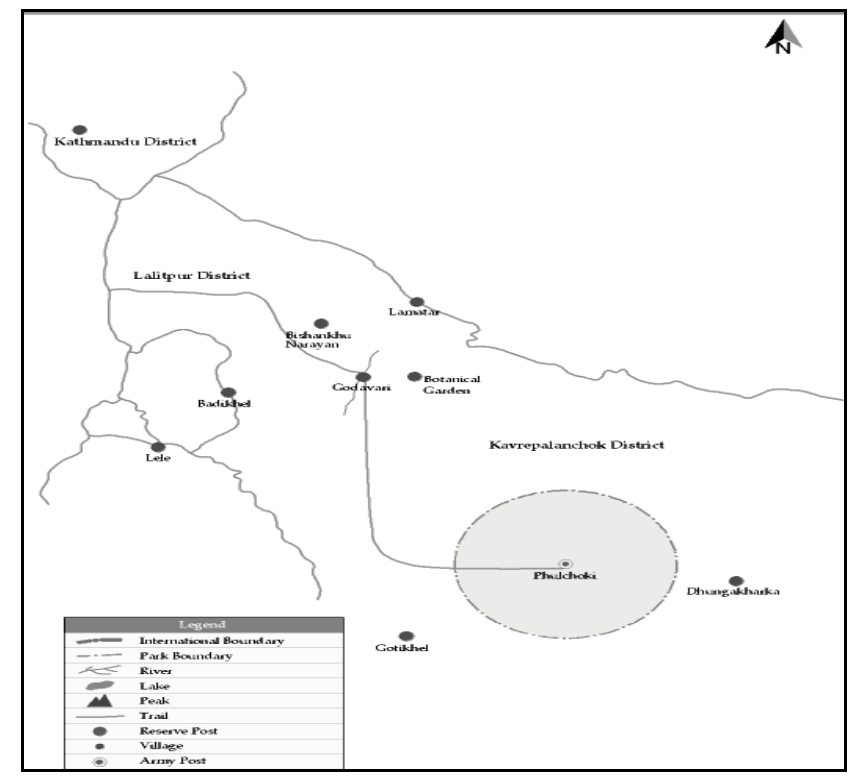

Figure 1 : Location Map of Study Area 
Phulchoki is important for the restricted-range species, such as spiny babbler (Turdoides nipalensis) and hoary-throated barwing (Sibia nipalensis). There are large areas of broad leaved temperate forests that are known to support significant populations of characteristic species of the Sino-Himalayan Temperate Forest biome (Baral and Inskipp 2005). Phulchoki's forests are internationally renowned for wildlife. It supports varieties of butterflies, including the rare golden emperor (Dilipa morgiana) and Kaiser-I-Hind (Teinopalpus imperialis). In addition, other smaller mammals found in this area are Indian muntjac (Muntiacus muntjak), yellow-throated marten (Martes flavigula), orange-bellied squirrel (Dremomys lokriah) and leopard (Panthera pardus) (Limbu and Gurung 1998).

\section{Methods}

The survey was carried out in January 2018 (winter season) and April 2018 (spring season). Fixed Radius Point Count method (Sarkar et al. 2009) was used and altogether 28 plots were established at four different sites (bus park area, mine area, community forest area and Botanical Garden area). Selection of sites was based upon the forest types and habitats. Each study site was divided into seven plots, and distance from one plot to another was $200 \mathrm{~m}$ and from one site to other was roughly $2 \mathrm{~km}$. About 2-3 days were allocated to each site during each visit. 30-minute time was allocated to see the birds at each plot. The observations were done during morning (7.00-11.00 AM) and evening (15.0017.00 PM). The peak activity for most of the birds lasts for 1 to $2 \mathrm{hrs}$ after the sunrise or before sunset. So, the time for observation started from early morning and lasted till evening. Birds were recorded by direct observation and call- count method. The birds were not captured or handled during the entire data collection period. Mist nets were not used and bright coloured dress was also avoided during surveys as it might scare the birds. The relative abundance of bird species was estimated on the basis of frequency of sightings and number of birds seen. The seasonal status of birds was evaluated on the basis of the presence or absence method (Thakur et al. 2010). Bird species richness was estimated by recording the number of observed bird species. Birds were observed using the Opticron Verano $8 \times 42$, RSPB $8 \times 42$ waterproof binocular and photographs were taken with a Canon Powershot $5 \times 40$ HS. In addition, field guides by Grimmett et al. (2011) and Grimmett et al. (2016) were used to identify the birds in the field.

\section{Data Analysis}

Shanon Wiener Diversity Index, 'H' (Shannon and Weaver 1949) was used to calculate seasonal bird diversity and species evenness which is given below: 
$\mathrm{H}=-\sum\left(\mathrm{P}_{\mathrm{i}} * \ln \mathrm{P}_{\mathrm{i}}\right)$

Species Evenness (E) was calculated using the formula:

$\mathrm{E}=(\mathrm{H} / \mathrm{Hmax})$

$\mathrm{H}$ value would be higher if the species are uniformly distributed in the group. Therefore, the higher value of $\mathrm{H}$ represents more diverse communities.

\section{Results and Discussion}

\section{Results}

A total of 78 species of birds belonging to 7 orders and 24 families were observed in the study area. The highest number of species found belong to order Passeriformes $(n=58)$ followed by Piciformes $(n=7)$, Columbiformes $(n=5)$, Ciconiformes $(n=3)$, Cuculiformes $(n=2)$, Psittaciformes $(n=2)$ and Strigiformes $(\mathrm{n}=1)$ (Figure 2).

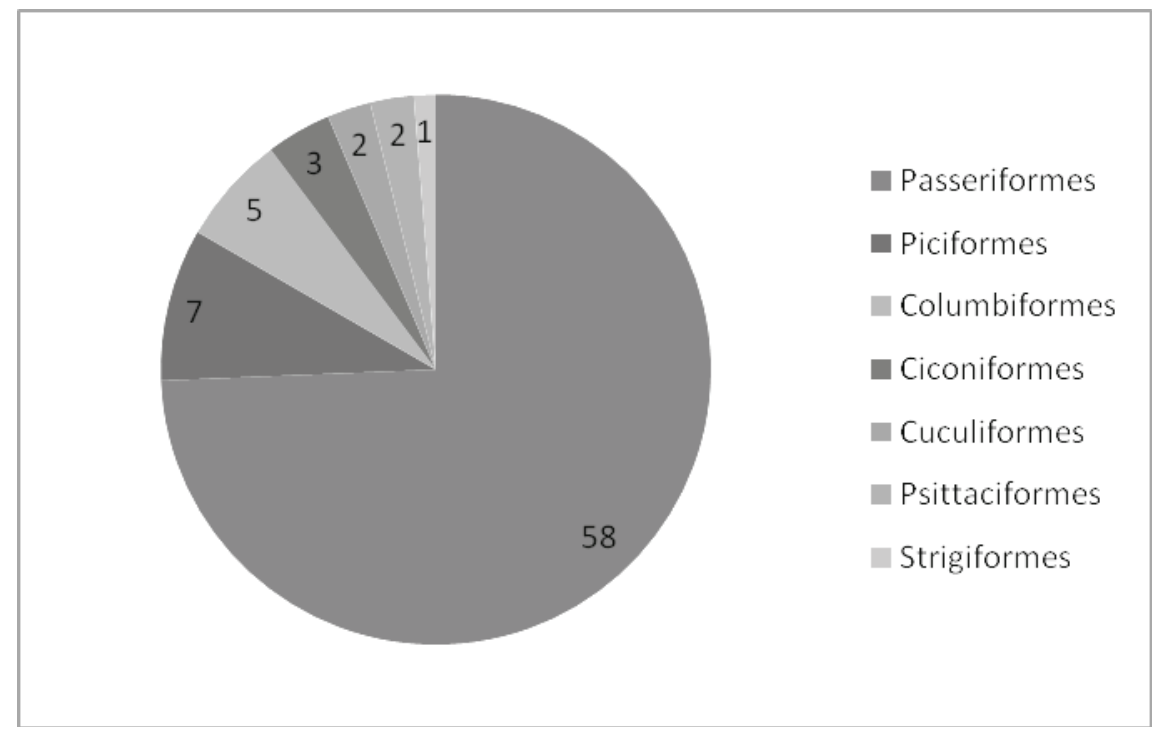

\section{Figure 2 : Order-wise Distribution of Bird Species}

The highest number of species found were of family Sylviidae $(n=14)$ followed by Muscicapidae $(n=13)$ and Corvidae $(n=8)$ and the least $(n=1)$ belonged to other 8 families.

The relative abundance of species was Very Common $(n=16)$, Common $(n=38)$, Uncommon $(n=9)$ and Rare $(n=15)$ (Figure 3). The highest number of species was found in Common followed by Very Common, Rare and Uncommon categories. 


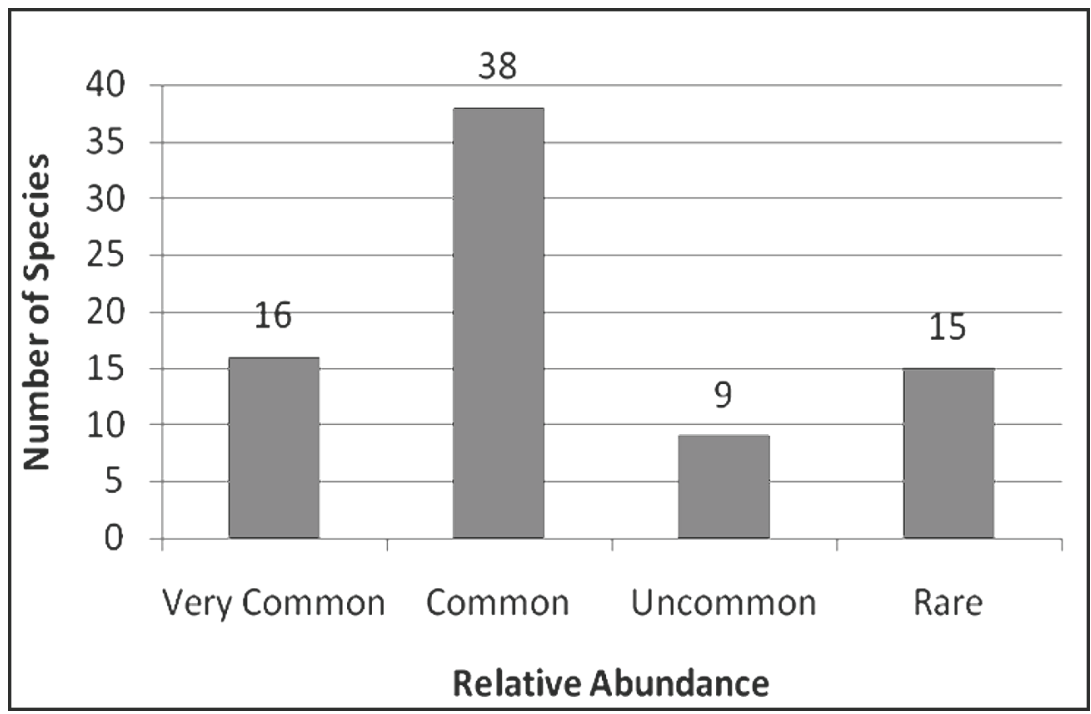

Figure 3 : Relative Abundance of Bird Species

The seasonal status of species varied during different seasons, such as spring $(\mathrm{n}=$ 50) and winter $(n=59)$ (Figure 4). Thus, the bird diversity was higher during the winter season than spring. Thirty species were found during both the winter and spring season.

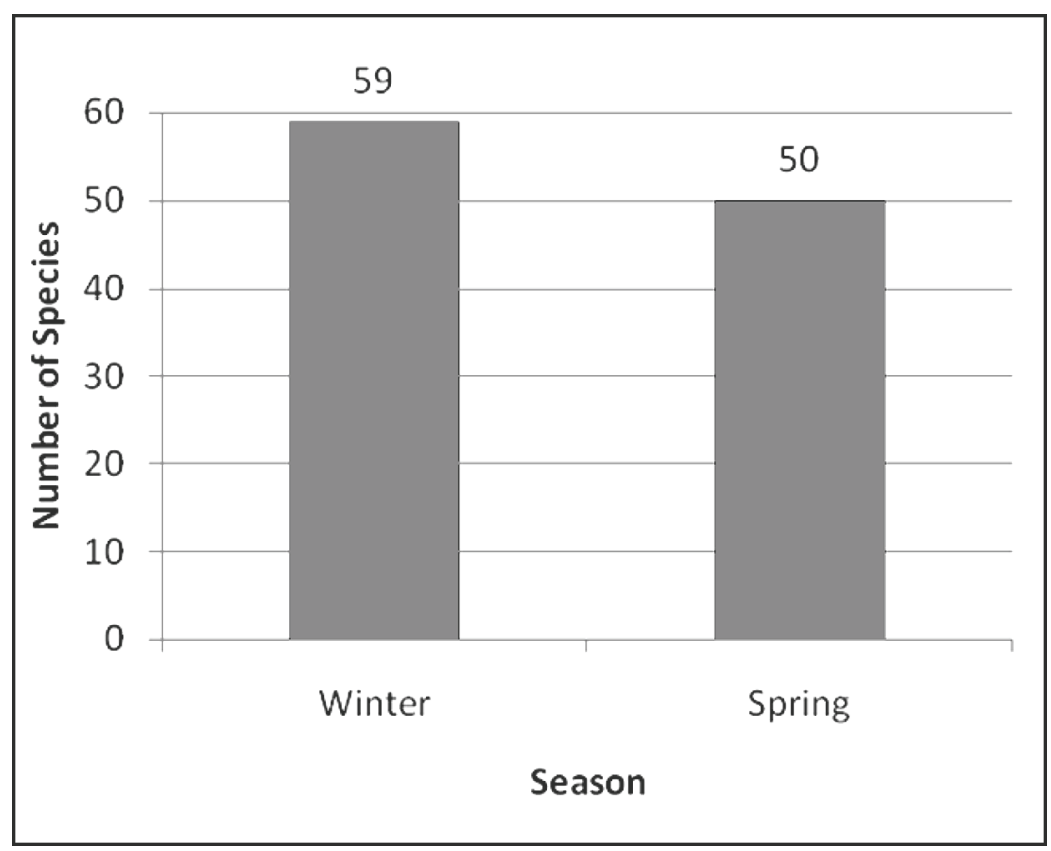

Figure 4 : Seasonal Status of Bird Species 
Shannon-Weinner Diversity Index showed that winter season $\left(\mathbf{H}^{\prime}=1.488\right)$ had more bird diversity than the spring season $\left(\mathbf{H}^{\prime}=1.169\right)$. Evenness Index also showed that birds were more evenly distributed during winter season $(\mathbf{E}=0.253)$ than the spring season $(E=0.207)$.

Species richness of the mine area $(n=29$ species) was seen the highest in winter season followed by community forest area ( $n=22$ species), Botanical Garden area $(n=19$ species) and bus park area ( $n=15$ species) (Figure 5). Similarly, in spring season the maximum number of bird species was recorded in the mine area, followed by community forest area, Botanical Garden area and bus park area where the numbers of bird species were $26,21,18$ and 11, respectively.

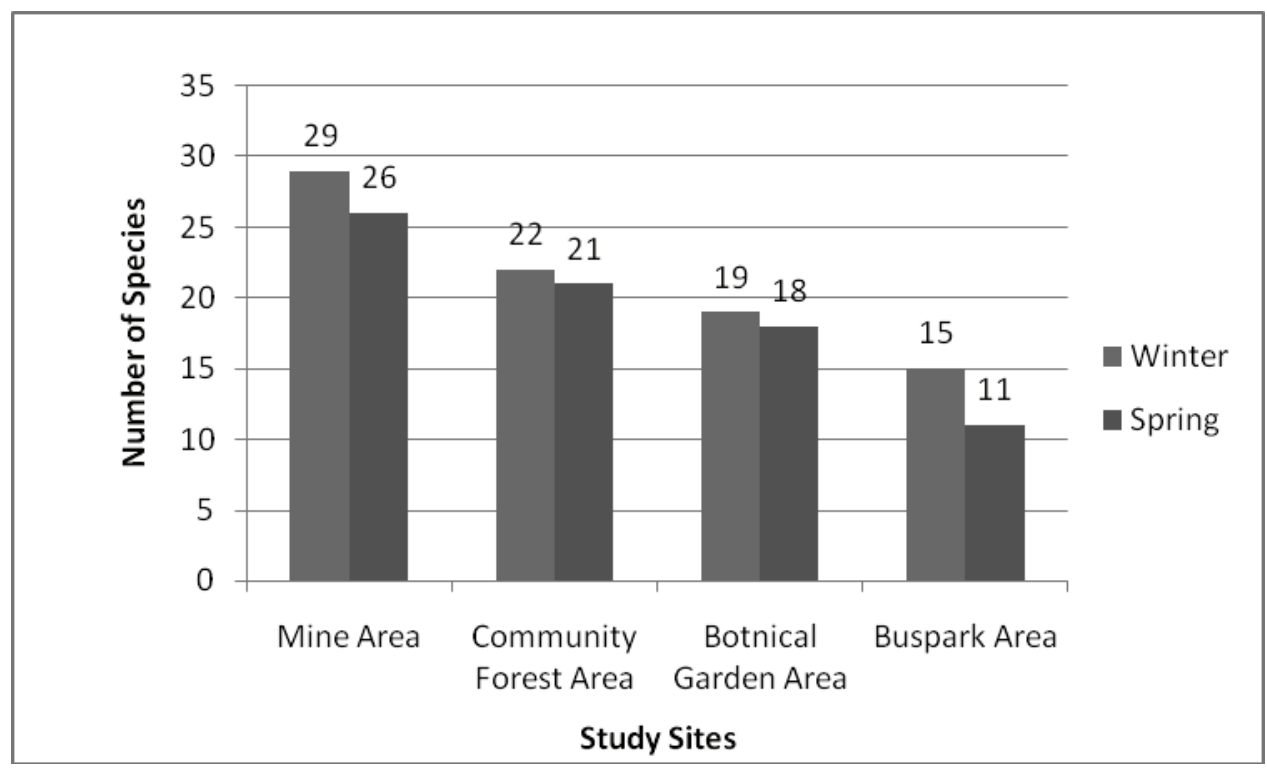

Figure 5 : Site-wise Distribution of Bird Species in Different Seasons

The analysis of data on residential status revealed that out of 78 species, 64 were residents, 10 winter visitors and 4 summer visitors.

\section{Discussion}

The area of Phulchoki is rich in bird species. However, more studies are required to undertake during different seasons and at various parts of Phulchoki hill in order to determine the total number of bird species and their distribution patterns. Giri and Chaudhary (2004) recorded 256 species of birds over an area of $50 \mathrm{~km}^{2}$ in Phulchoki Mountain, and the result of present study showed 78 species in a small area of $8 \mathrm{~km}^{2}$. The difference can be due to the time duration, season and size of the study area. 
The present study revealed that number of bird species in winter was higher than spring season. This shows that winter season was the most favorable for birds than the spring season because the climatic conditions are much better for altitudinal migrants as well as long distance winter migrants. However, winter migratory birds were found less because the birds come to Nepal from North Pole to evade the cold weather. They are mostly water birds as well as fish eating birds, and there is less number of wetlands in Phulchoki hill. Eventhough it has less number of wetland sites, it paves the way for the main path of migration of these birds from North Pole to South Pole due to the presence of dense forest. Similarly, summer migratory birds migrate to Nepal in search of food and to escape competitions for survival. Less fruiting as well as flowering trees are the major cause for declining of summer visitors. Natarajan (1992) reported that the population of birds varied throughout the year depending on the climatic condition and availability of food sources.

Maximum number of bird species were recorded in mining sites, which is a silence zone, hence was free from all kinds of disturbances and has wide range of trees that provide shelter as well as food and safety for birds. Similarly, least number was observed in the bus park area because of extensive human interference, construction activities and noise due to vehicles that rendered big threat to the species of avifauna. It could be the reason why species diversity was poor in the bus park area. On the other hand, day-by-day this area is becoming a commercial area. Therefore, it is difficult for avifauna to find the nesting locations and sheltering place or foraging in the bus park area. In Botanical Garden area, there are many natural and planted trees where birds foraged, took shelter and made nests. During the study period, it was observed that increasing number of picnic spots and interference of people in the forest area are mainly disturbing many shy and visiting bird species. The trees like Bar (Ficus bengalensis) and Pipal (Ficus religiosa) are the particular nesting sites of raptor species, and therefore, more number of such types of trees should be planted. Population of fruiting and flowering trees within the garden area can attract many frugivorous and insectivorous birds to live thereby. It is well known that birds are friends of human as they destroy lots of harmful insects and mosquitoes from the environment (Koli 2014). Therefore, a conservation and awareness plan should be launched by the government with the participation of local communities and institutions to save the resident as well as migratory birds, and also, to know about the ecological functions and values of avifauna.

\section{Conclusion}

Bird species richness and seasonal diversity were compared on the basis of different seasons. To achieve the results, two month time period during two seasons, winter (January 2018) and spring (April 2018) were chosen. A total of 78 
species of birds belonging to 7 orders and 24 families were recorded in the study area. The highest number of bird species $(n=57)$ were represented by order Passeriformes along with 14 families. 59 species belonging to 6 orders and 18 families were recorded during winter season, whereas 50 species representing 6 orders and 18 families were observed during spring season. Winter visitors outnumbered the spring visitors. The diversity index was higher in winter season $(\mathrm{H}=1.488)$ than spring season $(\mathrm{H}=1.169)$. It was also observed that the species were evenly distributed in winter season than in the spring season. Birds are decreasing in number due to increasing urbanization and encroachment of their natural habitat in Phulchoki hill.

\section{Acknowledgement}

The author would like to thank Dr. Hem Sagar Baral, Dr. Bhesh Bahadur Gurung, Mr. Kalyan Subedi and Mr. NirajanThapa for their helpful and insightful suggestions.

\section{Literature Cited}

Baral, H.S. (1995): Phulchoki: A paradise for birdwatchers. Sanctuary Asia, 15(5): 60-62.

Baral, H.S., Inskipp, C. (2005): Important Bird Areas in Nepal: Key Sites for Conservation.

Bird Conservation Nepal and BirdLife International, Kathmandu, Nepal and Cambridge, UK.

BCN, DNPWC. (2011): The State of Nepal's Birds. Bird Conservation Nepal and the Department of National Parks and Wildlife Conservation, Kathmandu, Nepal.

BCN, DNPWC. (2018): Birds of Nepal: An Official Checklist. Department of National Parks and Wildlife Conservation, Kathmandu, Nepal.

Bhushal, K. (2013): Migratory birds of Nepal and challenges in their conservation. Munal, 1/2.

Bibi, F., Ali, Z. (2013): Measurement of diversity indices of avian communities at Taunsa Barrage Wildlife Sanctuary. Pakistan Journal of Animal and Plant Sciences, 23:469-474.

BirdLife International. (2008): Bird Conservation Nepal Works with Community Forest Users Groups for Sustainable Forest Management. Downloaded from http:/ /www.birdlife.org on 28/08/2019. 
BirdLifeInternational. (2019): Country profile: Nepal. Available from http://www.birdlife.org/datazone/country/nepal [Date accessed: 10 February 2019].

Giri, T., Chaudhary, H. (2004): Additional sightings. Danphe, 13(1/2): 11.

Grimmett, R., Inskipp, C., Inskipp, T., Baral, H.S. (2000): Birds of Nepal. Helms Field Guide. Revised edition, Christopher Helm, London. (Nepali Version).

Grimmett, R., Inskipp, C., Inskipp, T. (2011): Birds of the Indian Subcontinent. 2nd edition, Helms Field Guide, Oxford University Press, India

Inskipp, C. (1989): Nepal's Forest Birds: Their Status and Observation. ICBP Monograph no. 4. International Council for Bird Preservation, Cambridge, UK.

Inskipp, C. (1993): Phulchoki. Nepal Bird Watching Club Bulletin, 2(1): 1-2.

Inskipp, C., Baral, H.S., Phuyal, S., Bhatt, T.R., Khatiwada, M., Inskipp, T., Khatiwada, A., Gurung, S., Singh, P.B., Murray, L., Poudyal, L., Amin, R. (2016): The Status of Nepal's Birds. The National Red List Series, Zoological Society of London, UK.

Jha, P.K. (2016): Status of migratory birds in Nepal. The Journal of University Grants Commission, 5(1): 67-77.

Jha, P.K., Sharma, C.K. (2018): Status of migratory birds in Nepal: A case study of Chitwan National Park. Joural of Indian Research, 6(2): 49-61.

Koli, V.K. (2014): Diversity and status of avifauna in Todgarh-Raoli Wildlife Sanctuary, Rajasthan, India. Journal of Asia-Pacific Biodiversity, 7: 401-407.

Lama, S. (1994): Additional sightings. Nepal Bird Watching Club Newsletter, 3(2): 2-3.

Limbu, M.S., Gurung, D. (1998): Phulchoki: A nature's paradise. Danphe, 7(1/2): $1-4$.

Natarajan, V. (1992): Wintering water birds at point Calimere, Tamil Nadu, India. Journal of Bombay Natural History Society, 89: 319-328.

Sarkar, N.J., Sultana, D., Jaman, M.F., Rahman, M.K. (2009): Diversity and population of avifauna of two urban sites in Dhaka, Bangladesh. Ecological Society (ECOS) Nepal, 16: 1-7.

Shannon, C.E., Weaver, W. (1949): The Mathematical Theory of Communication. University of Illinois Press, Urbana, Illinois. 144 pp.

Thakur, M.L., Mattu, V.K., Lal, H. (2010): Avifauna of Arki Hills, Solan (Himachal Pradesh), India. Indian Birds, 5: 162-166. 